\title{
Phosphorylation of fibrinogen by casein kinase 2
}

\author{
Maria D. GUASCH, Maria PLANA, Jose M. PENA and Emilio ITARTE* \\ Departament de Bioquímica, Facultat de Ciències, Universitat Autònoma de Barcelona, Bellaterra, Barcelona, Spain
}

Casein kinase 2 from rat liver cytosol phosphorylated human fibrinogen in a reaction that was not stimulated by $\mathrm{Ca}^{2+}$ or cyclic AMP, but was markedly inhibited by heparin, and proceeded at a similar rate when either ATP or GTP was used as phosphate donor. Analysis of casein kinase 2 by glycerol-density-gradient centrifugation showed that the activities towards fibrinogen, casein, phosvitin, high-mobility-group protein 14 and glycogen synthase coincided. Maximal incorporation into fibrinogen by casein kinase 2 averaged $1 \mathrm{~mol}$ of phosphate/mol of protein substrate, most of it in the $\alpha$-chain, although some phosphorylation of the $\beta$-chain was also detected. Analysis of phosphorylated $\alpha$-chain revealed that most of the phosphate was incorporated on serine. Phosphorylation of human fibrinogen was also performed by casein kinase 2 from human polymorphonuclear leucocytes, lymphocytes and platelets.

\section{INTRODUCTION}

Human fibrinogen is an hexameric protein $\left(\alpha_{2} \beta_{2} \gamma_{2}\right)$ which contains phosphorus covalently bound at two or more locations in the $\alpha$-chains (Doolittle et al., 1979). The physiological role for the presence of phosphate in fibrinogen is not totally clear, but it seems to affect its clotting time (Blomback et al., 1963). The synthesis of fibrinogen takes place in the liver, from where it is secreted to circulating blood. Studies on human fibrinogen (Blomback et al., 1972) and more recently on dog fibrinogen (Kudryk et al., 1982) have shown that the newly secreted fibrinogen is in the phosphorylated form, with phosphorylation occurring at a late secretory stage.

Several protein kinases have been shown to phosphorylate fibrinogen in vitro. These include the cyclic AMP-dependent protein kinase from pig muscle (Engstrom et al., 1980; Humble et al., 1981), the $\mathrm{Ca}^{2+}$-activated phospholipid-dependent protein kinase from rat brain (Papanikolau et al., 1982) and pig spleen (Humble et al., 1984), a human platelet kinase activity enhanced by interferon (Galabru et al., 1983; Krust et al., 1983) and rat liver cytosol casein kinase 1 (Itarte et al., 1983), but no fibrinogen kinase activity seems to be present in human blood plasma (Humble et al., 1981).

In addition to casein kinase 1, rat liver cytosol contains another casein kinase, designated casein kinase 2 , different from the other in its molecular and catalytic properties (Itarte et al., 1981). The presence of casein kinase 2 has also been detected in blood cells, such as human erythrocytes (Boivin \& Galand, 1979) and pig polymorphonuclear leucocytes (Pena et al., 1981). In the present paper we show that casein kinase 2 from rat liver and human blood cells phosphorylates fibrinogen in a reaction that is not stimulated by cyclic AMP or $\mathrm{Ca}^{2+}$ but that is inhibited by heparin.

\section{EXPERIMENTAL}

\section{Materials}

The source of all the reagents used in this work, including human fibrinogen and other protein substrates, was as previously reported (Itarte et al., 1983; Martos et al., 1985).

\section{Enzymes}

Rat liver casein kinases 1 and 2 were purified as previously described (Martos et al., 1985). The purified preparation of casein kinase 2 had a specific activity of about 90 units $/ \mathrm{mg}$ of protein and contained only the $M_{\mathrm{r}}-41000$ and $M_{\mathrm{r}}-27000$ polypeptides present in casein kinases 2 purified from other sources (Hathaway \& Traugh, 1982).

Human polymorphonuclear leucocytes, lymphocytes and platelets were isolated from the blood of healthy donors by using standard techniques with minor modifications (Pena et al., 1983). Casein kinase 2 was obtained from the different types of cells by chromatography on phosphocellulose and gel filtration on Bio-Gel A-1.5 m as described for the isolation of the protein kinases from pig polymorphonuclear leucocytes (Pena et al., 1981).

\section{Assays}

Casein kinase activity was assayed by measuring the incorporation of [ $\left.{ }^{32} \mathrm{P}\right] \mathrm{phosphate}$ from $\left[\gamma^{32} \mathrm{P}\right] \mathrm{ATP}$ into the different protein substrates as indicated previously (Huang \& Robinson, 1976; Itarte et al., 1983). In some experiments $\left[\gamma^{32} \mathrm{P}\right]$ GTP was used instead of $\left[\gamma^{32} \mathrm{P}\right]$ ATP, at the same final concentration. One unit of casein kinase is the amount of enzyme that incorporated $1 \mathrm{nmol}$ of [ $\left.{ }^{32} \mathrm{P}\right]$ phosphate from $\left[\gamma^{\left.-{ }^{82} \mathrm{P}\right] A T P}\right.$ into casein $(4 \mathrm{mg} / \mathrm{ml}) / \mathrm{min}$. Alkali-labile phosphate content of fibrinogen was determined by using 1-5 nmol of protein. Samples were incubated in $1 \mathrm{M}-\mathrm{NaOH}$ either at $37^{\circ} \mathrm{C}$ for $38 \mathrm{~h}$ or at $85^{\circ} \mathrm{C}$ for $60 \mathrm{~min}$ and then processed as described by Ames (1966), except that the volumes were halved to increase sensitivity.

Protein was determined by the method of Bradford (1976) and, for fibrinogen, also by its $A_{282}$ (Blomback et al., 1972).

\section{Analysis of ${ }^{32} \mathbf{P}$-labelled fibrinogen \\ Preparation of ${ }^{32} \mathrm{P}$-labelled fibrinogen phosphorylated by either casein kinase 1 or 2 , analysis by polyacrylamide- gel electrophoresis in the presence of $0.1 \%$ SDS, and identification of phosphoamino acids, were carried out as indicated previously (Itarte et al., 1983).}

* To whom correspondence should be addressed. 


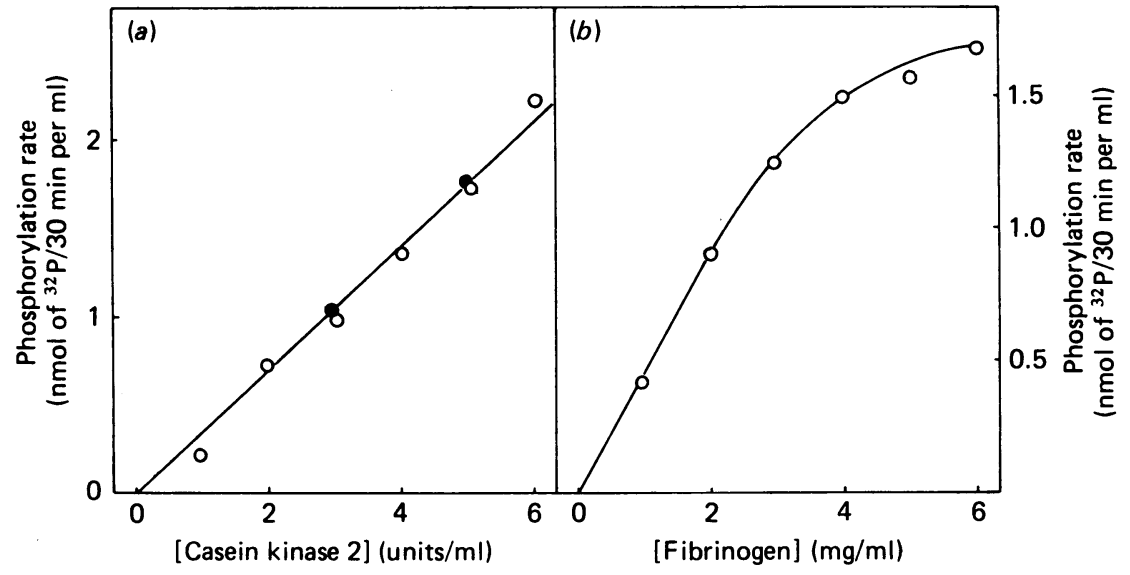

Fig. 1. Dependence of the initial rate of phosphorylation of fibrinogen on the concentration of casein kinase 2 and fibrinogen

The initial rate of phosphorylation by casein kinase 2 was determined under standard assay condition with either ATP $(O)$ or GTP (O) as phosphate donor. In $(a)$ the concentration of fibrinogen was kept constant $(2 \mathrm{mg} / \mathrm{ml})$ and that of casein kinase 2 was varied. In $(b)$ the concentration of casein kinase 2 was always 2 units $/ \mathrm{ml}$ and that of fibrinogen was varied, as indicated.

\section{Determination of the clotting time of fibrinogen}

The clotting time of fibrinogen, either control or after phosphorylation by casein kinase 1 or casein kinase 2, was measured with the Hemodiagnostic-Stago kit (no. 126691) from Boehringer-Mannheim.

\section{RESULTS}

\section{Phosphorylation of fibrinogen by casein kinase 2}

Purified liver casein kinase 2 phosphorylated fibrinogen in a reaction that was dependent on the concentration of protein kinase (Fig. 1a) and fibrinogen (Fig. 1b) in the assays. The apparent $K_{\mathrm{m}}$ value for fibrinogen, determined by double-reciprocal plots of the data shown in Fig. 1(b), was $2.8 \mathrm{mg} / \mathrm{ml}$. This value is higher than those for casein, glycogen synthase and the high-mobility-group protein 14 , which are in the range of $0.2-1 \mathrm{mg} / \mathrm{ml}$ (Martos et al., 1985). The maximal rate of phosphorylation of fibrinogen was only $4 \%$ of that of casein, but about half that of glycogen synthase. A similar rate of phosphorylation of fibrinogen by casein kinase 2 was observed when either GTP or ATP was used as phosphate donor (Fig. 1a).

Maximal phosphorylation by casein kinase 2 reached a plateau corresponding to $0.94 \pm 0.19 \mathrm{~mol}$ of ${ }^{32} \mathrm{P} / \mathrm{mol}$ of fibrinogen $\left(M_{\mathrm{r}} 340000\right)$. A similar value $(1.19 \mathrm{~mol}$ of ${ }^{32} \mathrm{P} / \mathrm{mol}$ of fibrinogen) was obtained when the alkali-labile phosphate incorporated was analysed chemically. In comparison, a value of $3.16 \pm 0.31 \mathrm{~mol}$ of ${ }^{32} \mathrm{P} / \mathrm{mol}$ of fibrinogen was achieved by phosphorylation by casein kinase 1.

Analysis of casein kinase 2 by glycerol-density-gradient centrifugation showed that the peak of activity towards fibrinogen coincided with those corresponding to the phosphorylation of other protein substrates such as casein (with either ATP or GTP as phosphate donor), phosvitin, glycogen synthase and high-mobility-group protein 14 (Fig. 2).

The phosphorylation of fibrinogen by casein kinase 2 was not stimulated by either cyclic AMP $(20 \mu \mathrm{M})$ or $\mathrm{Ca}^{2+}$ $(0.5 \mathrm{mM})$, but was markedly inhibited by heparin (Fig. 3) when either ATP or GTP was used as phosphate donor,

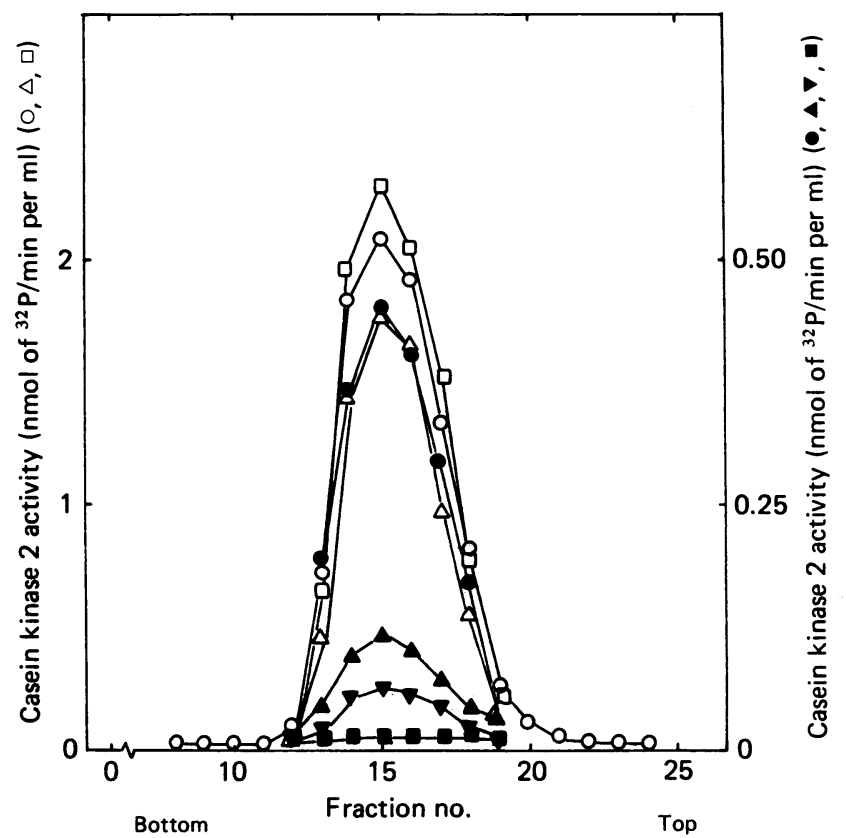

Fig. 2. Analysis of casein kinase 2 by glycerol-density-gradient centrifugation

A $0.1 \mathrm{ml}$ portion of purified casein kinase 2 was layered over an $8-30 \%(\mathrm{v} / \mathrm{v})$ glycerol density gradient $(4.3 \mathrm{ml})$ and centrifuged at $55000 \mathrm{rev} . / \mathrm{min}$ for $16 \mathrm{~h}$ at $4{ }^{\circ} \mathrm{C}$ with an SW 60 rotor in a Beckman L8-70 centrifuge. Fractions $(0.18 \mathrm{ml})$ were collected by piercing the bottom of the tube, and the protein kinase activity was assayed with [ $\left.\gamma-{ }^{32} \mathrm{P}\right] \mathrm{ATP}$ as phosphate donor and either in the absence $(\boldsymbol{D})$ or in the presence of one of the following substrates; $(O)$ casein $(4 \mathrm{mg} / \mathrm{ml}),(\triangle)$ phosvitin $(4 \mathrm{mg} / \mathrm{ml}),(\Theta)$ high-mobilitygroup protein $14(0.4 \mathrm{mg} / \mathrm{ml})$, (A) I-form glycogen synthase $(0.2 \mathrm{mg} / \mathrm{ml})$ or $(\nabla)$ fibrinogen $(2 \mathrm{mg} / \mathrm{ml})$. The activity on casein $(4 \mathrm{mg} / \mathrm{ml})$ with $\left[\gamma_{-32}{ }^{32}\right] \mathrm{GTP}$ as phosphate donor was also assayed $(\square)$.

with $50 \%$ inhibition occurring at $0.4 \mu \mathrm{g} / \mathrm{ml}$. Under similar conditions phosphorylation of fibrinogen by casein kinase 1 was essentially unaffected by low concentrations of heparin. 


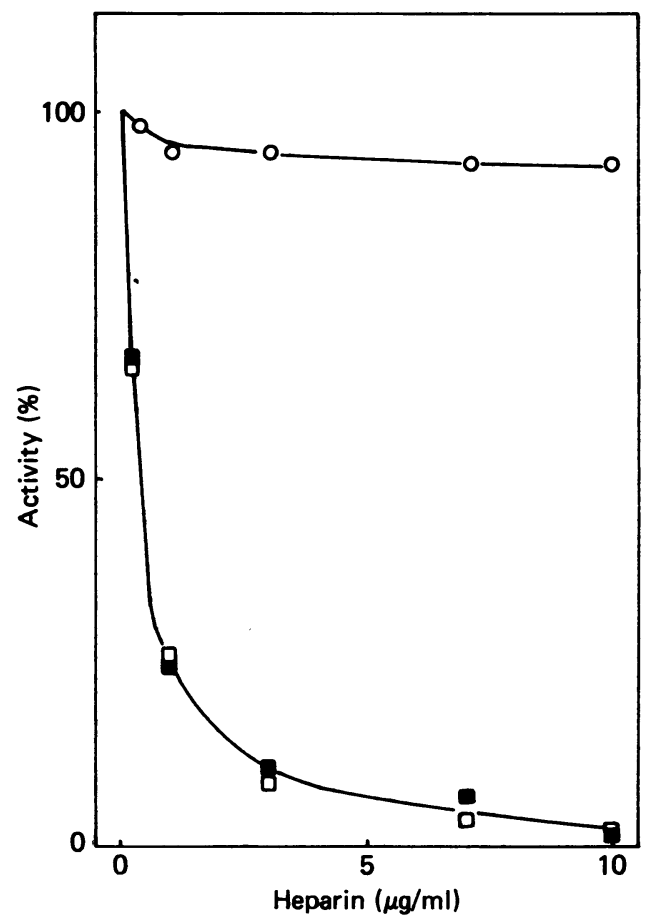

Fig. 3. Effect of heparin on the phosphorylation of fibrinogen by casein kinases 1 and 2

Phosphorylation of fibrinogen $(1 \mathrm{mg} / \mathrm{ml})$ by casein kinases $1(O)$ and $2(\square, \square)$ was carried out under standard assay conditions in the presence of various amounts of heparin, with either ATP $(O, \square)$ or GTP $(\square)$ as phosphate donor. Data are expressed as percentages of the activity in the absence of heparin.

\section{Analysis of phosphorylated fibrinogen}

Analysis by gel electrophoresis and autoradiography of fibrinogen phosphorylated by casein kinases 1 or 2 (Fig. 4) revealed that in both cases most of the phosphate was incorporated into the $\alpha$-chain. However, casein kinase 2 also considerably phosphorylated the $\beta$-chain, but not the $\gamma$-chain, whereas casein kinase 1 slightly phosphorylated the $\gamma$-chain.

Phosphoamino acid analysis of the $\alpha$-chain of fibrinogen phosphorylated by casein kinase 2 showed that most of the phosphate was incorporated as phosphoserine, although some phosphothreonine, representing 10-15\% of the total radioactivity, was also observed.

Characteristics of casein kinase $\mathbf{2}$ from human blood cells

The properties of the casein kinases 2 purified from human polymorphonuclear leucocytes, lymphocytes and platelets, such as their apparent $M_{\mathrm{r}}(150000)$, apparent $K_{\mathrm{m}}$ for casein $(0.8 \mathrm{mg} / \mathrm{ml})$, ATP $(15 \mu \mathrm{M})$ and GTP $(22 \mu \mathrm{M})$, as well as their stimulation by $\mathrm{Mg}^{2+}\left(K_{\mathrm{a}} 1.5 \mathrm{mM}\right)$, were very similar, and resemble those reported for casein kinase II from erythroid cells (Hathaway \& Traugh, 1982; Boivin \& Galand, 1979), casein kinase 2 from rat liver cytosol (Itarte et al., 1981) and other type II casein kinases present in different mammalian tissues (Hathaway \& Traugh, 1982).

All these human blood-cell casein kinases 2 phosphorylated human fibrinogen; the rate of the reaction depended on the amount of casein kinase present, and the maximal

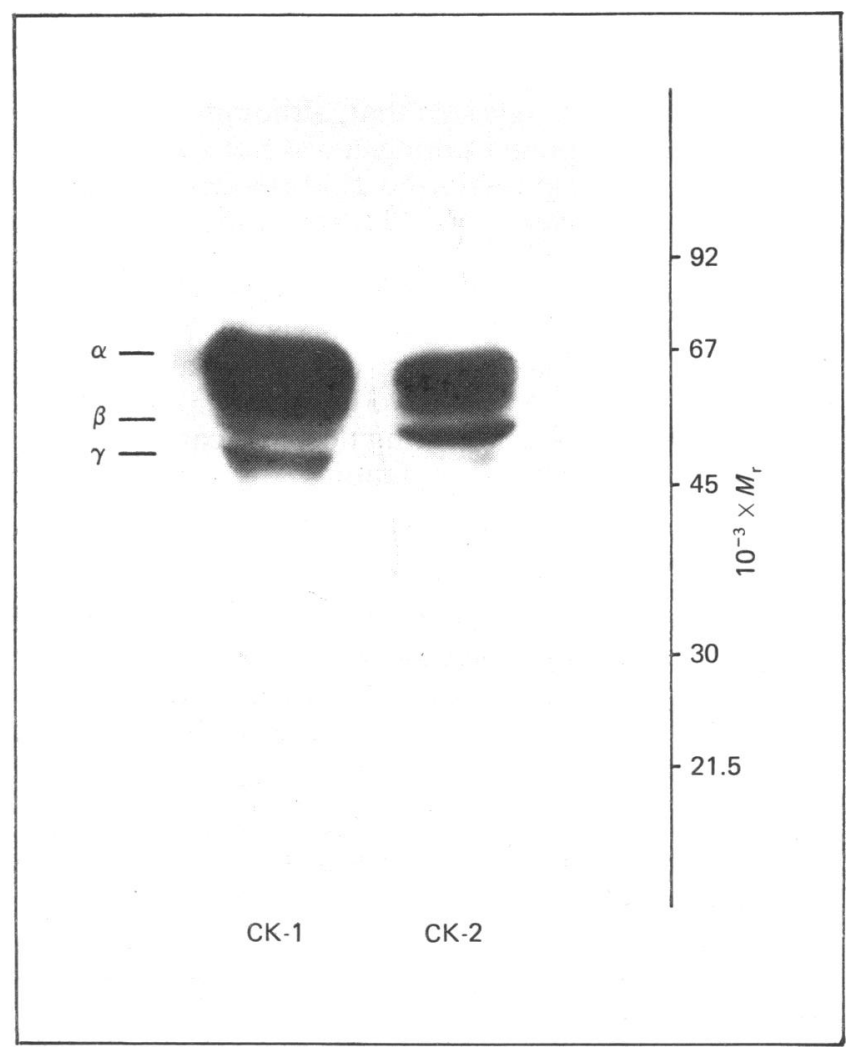

Fig. 4. Analysis of phosphorylated fibrinogen by slab-gel electrophoresis

Samples of fibrinogen phosphorylated by either casein kinase $1(\mathrm{CK}-1)$ or casein kinase 2 (CK-2) were subjected to electrophoresis in a 7-16\%-polyacrylamide-gradient slab gel containing $0.1 \%$ SDS and then autoradiographed.

Table 1. Effectors of the phosphorylation of fibrinogen by human casein kinase 2

The activity of casein kinase 2 from human lymphocytes and platelets on fibrinogen $(2.6 \mathrm{mg} / \mathrm{ml})$ was assayed in the presence of the indicated compounds. Values are expressed as percentages of the activity determined with ATP as phosphate donor, without additions.

\begin{tabular}{lccc}
\hline & & \multicolumn{2}{c}{$\begin{array}{c}\text { Activity }(\%) \text { of } \\
\text { casein kinase } 2 \text { from: }\end{array}$} \\
\cline { 3 - 4 } $\begin{array}{l}\text { Phosphate } \\
\text { donor }\end{array}$ & Addition & $\begin{array}{c}\text { Human } \\
\text { lymphocytes }\end{array}$ & $\begin{array}{c}\text { Human } \\
\text { platelets }\end{array}$ \\
\hline \multirow{2}{*}{ ATP } & None & 100 & 100 \\
& $20 \mu \mathrm{M}$-cyclic AMP & 102 & 93 \\
& $0.5 \mathrm{mM}^{-C a C l} \mathrm{Ca}_{2}$ & 96 & 90 \\
GTP & Heparin $(1 \mu \mathrm{g} / \mathrm{ml})$ & 45 & 34 \\
& None & 107 & 103 \\
\hline
\end{tabular}

${ }^{32} \mathrm{P}$ incorporation reached a value close to $1 \mathrm{~mol}$ of ${ }^{32} \mathrm{P} / \mathrm{mol}$ of fibrinogen. In addition, phosphorylation of fibrinogen by these enzymes was not activated by cyclic AMP or $\mathrm{Ca}^{2+}$, was inhibited by heparin, and proceeded at a similar rate when either ATP or GTP was used as substrate (Table 1). 
Influence of phosphorylation on the clotting time of fibrinogen

Years ago it was suggested that, although the presence of phosphate in human fibrinogen was not a requirement for clotting, dephosphorylation of fibrinogen by alkaline phosphatase increased its clotting time moderately (Blomback et al., 1963).

When the clotting time for samples of fibrinogen $(1.6 \mathrm{mg} / \mathrm{ml})$, control or phosphorylated by rat liver cytosol casein kinase 1 or casein kinase 2, was determined, values of $31 \pm 1,31 \pm 2$ and $32 \pm 2 \mathrm{~s}$ were obtained respectively, indicating no significant change in this parameter by phosphorylation.

\section{DISCUSSION}

The possible role of casein kinase 2 in the control of physiological processes has gained considerable support in recent years owing to the evidence that this enzyme phosphorylates in vitro several biologically important proteins such as glycogen synthase (Huang et al., 1982), the regulatory subunit of type II cyclic AMP-dependent protein kinase (Carmichael et al., 1982) and high-mobilitygroup protein 14 (Walton \& Gill, 1983). Furthermore, the phosphorylation of these substrates has been shown to take place at the same site(s) that are phosphorylated in vivo under different physiological conditions (Parker et al., 1982; Carmichael et al., 1982; Walton \& Gill, 1983). The data obtained here on the co-migration of activities on glycerol-density-gradient centrifugation, together with the ability to use GTP as phosphate donor and the strong inhibition by heparin, clearly show that fibrinogen is also a substrate for casein kinase 2 .

The maximal phosphorylation of fibrinogen achieved by casein kinase 2 is lower than that by casein kinase 1 , the cyclic AMP-dependent protein kinase (Engstrom et al., 1980) or the $\mathrm{Ca}^{2+}$-activated phospholipid-dependent protein kinase (Humble et al., 1984). The $K_{\mathrm{m}}$ for fibrinogen of casein kinase $2(2.8 \mathrm{mg} / \mathrm{ml})$ is higher than that of the $\mathrm{Ca}^{2+}$-activated phospholipid-dependent protein kinase $(0.1-0.2 \mathrm{mg} / \mathrm{ml}$, determined at $\mathrm{pH} 6.5)$ (Humble et al., 1984), but lower than those of casein kinase $1(11.3 \mathrm{mg} / \mathrm{ml})$ (Itarte et al., 1983) and the cyclic AMP-dependent protein kinase $(>8 \mathrm{mg} / \mathrm{ml}$ ) (Engstrom et al., 1980). If the data on the concentrations of these protein kinases in liver cells (Kuo et al., 1980; Martos et al., 1985) and their activity on fibrinogen relative to the preferred substrates histone or casein in the $\mathrm{pH} 7.0-7.5$ range (Engstrom et al., 1980; Itarte et al., 1983; Humble et al., 1984; the present paper) are taken together, their concentration as fibrinogen kinases (at $2 \mathrm{mg}$ of fibrinogen $/ \mathrm{ml}$ ) will be approx. $0.05 \mathrm{unit} / \mathrm{ml}$ for the cyclic AMP-dependent protein kinase, $0.2 \mathrm{unit} / \mathrm{ml}$ for the $\mathrm{Ca}^{2+}$-activated phospholipid-dependent protein kinase, $0.32 \mathrm{unit} / \mathrm{ml}$ for casein kinase 1 and $0.15 \mathrm{unit} / \mathrm{ml}$ for casein kinase 2.

Phosphorylation of fibrinogen may affect at least two processes in which this protein is involved. One is the clotting time, as pointed out by Blomback et al. (1963). In this regard, the data obtained here indicate that phosphorylation by either casein kinase 1 or casein kinase 2 does not seem to alter the coagulability of fibrinogen. To our knowledge, no data are available on the possible effect of phosphorylation by other protein kinases on this parameter. Phosphorylation also seems to be related to the secretion of fibrinogen into the circulating blood. The presence of casein kinase 2 in the liver, whence fibrinogen is secreted in a phosphorylated form (Kudryk et al., 1982), suggests that the potential involvement of this enzyme in fibrinogen phosphorylation cannot be disregarded.

This work was supported by grant no. $2565 / 83$ from the Spanish 'Comisión Asesora del Investigación Científica y Técnica' of Ministerio de Educación y Ciencia.

\section{REFERENCES}

Ames, B. N. (1966) Methods Enzymol. 8, 115-118

Blomback, B., Blomback, M. \& Searle, J. (1963) Biochim. Biophys. Acta 74, 148-151

Blomback, B., Hassel, B., Iwanaga, S., Reuterby, J. \& Blomback, M. (1972) J. Biol. Chem. 247, 1496-1512

Boivin, P. \& Galand, C. (1979) Biochem. Biophys. Res. Commun. 89, 7-16

Bradford, M. M. (1976) Anal. Biochem. 72, 248-254

Carmichael, D. F., Geahlen, R. L., Allen, S. M. \& Krebs, E. G. (1982) J. Biol. Chem. 257, 10440-10445

Doolittle, R. F., Watt, K. W. K., Cottrell, B. A., Strong, D. D. \& Riley, M. (1979) Nature (London) 280, 464-468

Engstrom, L., Edlung, B., Ragnarsson, U., Dahlqvist-Edberg, U. \& Humble, E. (1980) Biochem. Biophys. Res. Commun. 96, 1503-1507

Galabru, J., Krust, B. \& Hovanessian, A. G. (1983) Biochem. Biophys. Res. Commun. 113, 370-376

Hathaway, G. M. \& Traugh, J. A. (1982) Curr. Top. Cell. Regul. 21, 101-127

Huang, K.-P. \& Robinson, J. C. (1976) Anal. Biochem. 72, 593-599

Huang, K.-P., Itarte, E., Singh, T. J. \& Akatsuka, A. (1982) J. Biol. Chem. 257, 3236-3242

Humble, E., Forsberg, P. O., Bergstrom, G., Edlund, B. \& Engstrom, L. (1981) FEBS Lett. 131, 132-136

Humble, E., Heldin, P., Forsberg, P. O. \& Engstrom, L. (1984) J. Biochem. (Tokyo) 95, 1435-1443

Itarte, E., Mor, M. A., Salavert, A., Pena, J. M., Bertomeu, J. F. \& Guinovart, J. J. (1981) Biochim. Biophys. Acta 658, 334-347

Itarte, E., Plana, M., Guasch, M. D. \& Martos, C. (1983) Biochem. Biophys. Res. Commun. 117, 631-636

Krust, B., Galabru, J. \& Horanessian, A. G. (1983) Biochem. Biophys. Res. Commun. 117, 350-357

Kudryk, B., Okada, B., Redman, C. M. \& Blomback, B. (1982) Eur. J. Biochem. 125, 673-682

Kuo, J. F., Anderson, R. G. G., Bradley, C. W., Mackerlova, L., Salomonsson, I., Brackett, N. L., Katoh, N., Shoji, M. \& Wrenn, R. W. (1980) Proc. Natl. Acad. Sci. U.S.A. 77, 7039-7043

Martos, C., Plana, M., Guasch, M. D. \& Itarte, E. (1985) Biochem. J. 225, 321-326

Papanikolau, P., Humble, E. \& Engstrom, L. (1982) FEBS Lett. 143, 199-204

Parker, P. J., Embi, N., Caudwell, F. B. \& Cohen, P. (1982) Eur. J. Biochem. 124, 47-55

Pena, J. M., Cusso, R. \& Itarte, E. (1981) Biochem. J. 193, 829-837

Pena, J. M., Itarte, E., Domingo, A. \& Cusso, R. (1983) Cancer Res. 43, 1172-1175

Walton, J. M. \& Gill, G. M. (1983) J. Biol. Chem. 258, $4440-4446$ 